\title{
KEMAMPUAN BERPIKIR ALJABAR SISWA SEKOLAH PENDIDIKAN DASAR KELAS V DAN KELAS VII: CROSS-SECTIONAL STUDY
}

\section{ALGEBRAIC THINKING ABILITY IN BASIC EDUCATION GRADE V AND GRADE VII: CROSS-SECTIONAL STUDY}

\author{
Dian Permatasari \\ Program Pasca Sarjana, Universitas Negeri Yogyakarta, Yogyakarta \\ E-mail: dian.permatasari750@gmail.com \\ Idris Harta \\ Universitas Muhammadiyah Surakarta, Surakarta \\ E-mail: idrisharta@gmail.com
}

\begin{abstract}
The study aimed to describe 1) students' algebraic thinking ability of elementary school grade $V, 2$ ) students' algebraic thinking ability of junior high school grade VII, and 3) the development of students' algebraic thinking ability from elementary school kelas $V$ to junior high school grade VII. This study was a cross-sectional design with quantitive descriptive approach. The subjects of this study were 77 students of elementary school grade $V$ and 95 students of junior high school grade VII. The sampling technique method used was stratified purposive sampling techniques and of analysis techniques with a descriptive analysis. The instrument used were algebraic thinking problems that consist of 3 components, namely, generational, transformational, and global meta-level activity. The results showed that 1) the students' algebraic thinking ability of elementary school grade $V$ was in the medium criteria; 2) the students' algebraic thinking ability of junior high school grade VII was in medium criteria; 3) the average of gain score of students in junior high school grade VII was higher than students in elementary school grade $V$ and students in elementary school grade $V$ because lementary school students grade $V$ until junior high school grade VII undergo a transition of thinking processes from arithmetic thinking to algebra thinking gradually, from simple cases to more complex cases. Generally, students of grade $V$ and VII have moderate algebraic thinking skills. However, the ability of students of grade VII is higher than students of grade $V$ because they have formally obtained algebra material.
\end{abstract}

Keywords: algebraic thinking, basic education, generational, transformational, global metalevel

\begin{abstract}
Abstrak: Penelitian ini bertujuan untuk mendeskripsikan 1) kemampuan berpikir aljabar siswa Sekolah Dasar kelas $V$, 2) kemampuan berpikir aljabar siswa Sekolah Menengah Pertama kelas VII, dan 3) perkembangan kemampuan berpikir aljabar siswa dari sekolah dasar hingga sekolah menengah. Penelitian ini merupakan penelitian cross-sectional dengan pendekatan deskriptif kuantitatif. Subjek penelitian ini 77 siswa SD kelas V dan 95 siswa SMP kelas VII. Penentuan subjek penelitian dilakukan dengan teknik stratified purposive sampling dengan teknik analisis deskriptif. Instrumen yang digunakan berupa tes kemampuan berpikir aljabar yang memuat 3 komponen kegiatan yaitu kegiatan generasional, transformasional, dan global meta-level. Hasil penelitian menunjukkan bahwa: 1) kemampuan berpikir aljabar siswa SD kelas V berada dalam kriteria sedang; 2) kemampuan berpikir aljabar siswa SMP kelas VII berada dalam kriteria sedang; 3) rata-rata kemampuan siswa SMP kelas VII lebih tinggi dibanding rata-rata siswa SD kelas V karena siswa SD kelas V sampai dengan SMP kelas VII mengalami suatu transisi proses berpikir dari berpikir
\end{abstract}


aritmatika menuju berpikir aljabar secara bertahap, mulai dari kasus sederhana sampai dengan kasus yang lebih kompleks. Kesimpulan, siswa kelas $V$ dan kelas VII rata-rata memiliki kemampuan berpikir aljabar sedang. Namun, kemampuan siswa kelas VII lebih tinggi daripada siswa kelas $V$ karena siswa Kelas VII telah memperoleh materi aljabar secara formal.

Kata kunci: berpikir aljabar, pendidikan dasar, generasional, transformasional, global metalevel

\section{PENDAHULUAN}

Dalam setiap jenjang pendidikan, matematika adalah salah satu mata pelajaran yang harus dikuasai siswa. Matematika memiliki peranan penting untuk membantu siswa menghadapi masalah kehidupan sehari-hari dan mengembangkan proses berpikir logis siswa. Dalam matematika, terdapat beberapa materi yang harus dikuasai, salah satunya adalah aljabar.

Aljabar adalah cara untuk menyatakan generalisasi mengenai bilangan, kuantitas, relasi, dan fungsi (Watson, 2007). Hal ini sejalan dengan Taylor-Cox (2003) bahwa aljabar adalah generalisasi dari ide-ide aritmatika di mana nilainilai dan variabel yang tidak diketahui dapat ditemukan untuk memecahkan masalah. Dengan demikian dapat disimpulkan bahwa aljabar adalah generalisasi dari ide-ide aritmatika yang berhubungan dengan pernyataan dengan variabel dan nilai-nilai yang tidak diketahui untuk memecahkan masalah. Permasalahan yang dapat diselesaikan dengan aljabar bukan hanya masalah yang abstrak melainkan juga masalahmasalah kehidupan sehari-hari dalam berbagai konteks.

Aljabar berperan penting dalam menyelesaikan masalah matematika lanjut, sains, bisnis, ekonomi, perdagangan, komputasi dan masalah lain dalam kehidupan sehari-hari (Booker, 2009). Oleh karena itu, aljabar dijadikan sebagai salah satu dari lima standar isi pada Principles and Standards NCTM (National Council of Teacher of Mathematics) yang harus dipelajari siswa mulai dari tingkat TK sampai tingkat menengah. Hal tersebut dimaksudkan agar siswa dapat mengintegrasikan pengalaman pemikiran aljabar sejak dini (NCTM, 2000). Aljabar sendiri bukan hanya himpunan fakta dan teknik, tetapi merupakan cara berpikir (Lew, 2004). Dengan demikian, aljabar dapat diterapkan dalam pembelajaran untuk mengembangkan kemampuan berpikir matematika siswa yang disebut berpikir aljabar (algebraic thinking).

Berpikir aljabar adalah elemen penting dan mendasar dari berpikir matematika dan penalaran matematika (Windsor, 2008). Berpikir aljabar melibatkan berbagai strategi kognitif untuk membantu memahami konsep matematika yang lebih kompleks. Berpikir aljabar akan muncul ketika seseorang menemukan dan menyatakan struktur dalam konteks memecahkan masalah yang berkaitan dengan bilangan atau model dari berbagai situasi.

Driscoll (dalam Panasuk, 2010), mengatakan bahwa berpikir aljabar adalah kapasitas untuk merepresentasikan situasi kuantitatif sehingga hubungan antar variabel menjadi lebih terlihat. Menurut Inganah (2016), berpikir tentang aljabar adalah cara yang digunakan dalam manipulasi simbol, sedangkan berpikir aljabar merupakan cara untuk menyelesaikan masalah kuantitatif dengan menganalisis hubungan serta menggunakan simbol. Berdasarkan pengertian yang disampaikan di atas, dapat disimpulkan bahwa berpikir aljabar adalah proses dimana siswa membuat relasi antarkuantitas, menemukan pola dari suatu situasi kontekstual matematika tertentu, dan menyusun generalisasinya melalui representasi dan manipulasi simbolik secara formal. Kieran (2004) membagi aljabar sekolah dalam kegiatan yang dilakukan 
siswa dalam mengerjakan soal-soal aljabar siswa yaitu: 1) kegiatan generasional (generational activity) yang melibatkan pembentukan pernyataan dan persamaan sebagai objek dari aljabar; 2) kegiatan transformasi (transformational activity) berhubungan dengan mengubah bentuk pernyataan atau persamaan untuk mempertahankan kesetaraan; dan 3) kegiatan level-meta global (global metalevel activity) adalah suatu kegiatan dimana kegiatan aljabarnya digunakan sebagai alat tetapi tidak benar-benar aljabar terlihat secara eksklusif. Ketiga kegiatan tersebut merupakan komponen-komponen yang berdiri sendiri, bukan merupakan tingkatan dalam berpikir aljabar. Lebih lanjut, Radford (2006) merumuskan beberapa karakteristik berpikir aljabar yaitu 1) berhubungan dengan sesuatu yang tidak pasti yang sesuai dengan objek dasar aljabar seperti sesuatu yang tidak diketahui, variabel, dan parameter; 2) objek yang tidak tentu yang diselesaikan secara analitis; dan 3) penggunaan simbol tertentu untuk mendesain objek tersebut.

Berpikir aljabar adalah habit of mind siswa yang diperoleh melalui pembelajaran yang secara terus-menerus untuk mendukung kemampuan untuk berpikir, menjelaskan, dan membenarkan hubungan yang umum dalam aritmatika, geometri, dan sebagainya. Dengan kata lain, berpikir aljabar membangun konsep-konsep matematika yang lainnya. Oleh karena itu, berpikir aljabar sangat penting untuk siswa.

Di Indonesia, berpikir aljabar belum terdapat dalam kurikulum SD. Berbeda dengan di Indonesia, di beberapa negara maju seperti negara Cina, Singapura, dan Korea Selatan, berpikir aljabar merupakan salah satu topik secara implisit disisipkan ke dalam kurikulum SD (Ferrucci, 2004). Terdapat perbedaan yang cukup signifikan antara negara-negara tersebut dan Indonesia dilihat dari hasil TIMSS 2011 (Tabel 1).

Di Indonesia, berdasarkan Permendikbud Nomor 24 Tahun 2016, Permendikbud Nomor 64
Tabel 1 Hasil TIMMS Domain Aljabar

\begin{tabular}{cc}
\hline Negara & Skor \\
\hline Cina & 628 \\
Korea & 617 \\
Singapura & 611 \\
Indonesia & 392 \\
\hline
\end{tabular}

Negara-negara yang telah memasukkan berpikir aljabar dalam kurikulum memiliki skor TIMSS yang lebih tinggi dibandingkan dengan Indonesia.

Tahun 2013, dan Permendiknas Nomor 23 Tahun 2006, topik aljabar dipelajari awal sekolah menengah pertama baik pada kurikulum 2013 edisi revisi, kurikulum 2013, maupun KTSP. Sementara, di sekolah dasar lebih menekankan pada bilangan asli dan pecahan, geometri dan pengukuran, dan statistika (Kementerian Pendidikan dan Kebudayaan, 2016; Kementerian Pendidikan dan Kebudayaan, 2013; Departemen Pendidikan Nasional, 2006). Dengan kata lain, selama masa sekolah dasar kurang lebih enam tahun, siswa telah belajar mengenai aritmatika. Siswa belajar mengenai bilangan-bilangan, operasi hitung, serta sifat-sifatnya di sekolah dasar.

Menurut Hidayanto (2014), proses berpikir dari kelas I sampai kelas V SD fokus pada proses berpikir aritmatika, sementara proses berpikir siswa kelas VIII di SMP dituntut proses berpikir aljabar. Oleh karena itu, dari SD kelas V sampai dengan SMP kelas VII, terjadi suatu proses transisi proses berpikir dari aritmatika menuju berpikir aljabar secara bertahap. Berdasarkan hasil penelitian yang dilaksanakan oleh Proulx (2006) dimana transisi dari berpikir aritmetika ke berpikir aljabar merupakan langkah yang paling sulit dalam kehidupan matematika siswa. Transisi dari berpikir aritmatika ke berpikir aljabar tersebut tidak selalu berjalan baik. Dengan demikian, siswa harus melakukan banyak penyesuaian untuk belajar aljabar di sekolah menengah. 
Sekolah Dasar (SD) adalah salah satu jenjang pendidikan di Indonesia. Rata-rata usia anak SD adalah 7-12 tahun. Dengan demikian, teori perkembangan kognitif Piaget, siswa sekolah dasar berada dalam tahapan operasional konkret. Tahapan ini merupakan tahapan awal berpikir rasional. Menurut Dahar (2006), pada tahapan ini anak memiliki operasi-operasi logis yang dapat diterapkannya pada masalahmasalah yang konkret. Apabila menghadapi pertentangan antara pikiran dan persepsi, anak memilih mengambil keputusan logis. Berbeda dengan siswa SMP, rata-rata usia untuk siswa sekolah menengah pertama adalah 12-15 tahun. Dengan demikian, teori perkembangan kognitif Piaget, siswa sekolah menengah berada dalam tahapan operasional formal. Menurut Dahar (2006), Feldman (2011), dan Ormrod \& Davis (2012) tahapan operasional formal dimulai dari usia 11 hingga dewasa. Pada tahap ini, individu bergerak di luar penalaran hanya tentang pengalaman konkret dan berpikir secara lebih abstrak, idealis, dan cara-cara yang logis (Santrock, 2011). Berpikir tidak lagi terikat pada peristiwa yang diamati di lingkungan tetapi memanfaatkan logika untuk menyelesaikan masalah (Feldman, 2011).

Disisi lain, berdasarkan penelitian longitudinal yang dilaksanakan oleh Britt dan Irwin (2008) dan Radford (2010) menyimpulkan bahwa berpikir aljabar dapat diakses oleh semua siswa khususnya sekolah dasar (Radford 2010) dan sekolah menengah pertama dan hal ini menunjukkan perkembangan kemampuan berpikir aljabar. Di Indonesia, penelitian mengenai berpikir aljabar banyak dilakukan seperti penelitian dari Hidayanto (2014), Patton dan Santos (2012) serta Nursuprianah dan Hayatun (2013) tetapi subjek penelitian-penelitian tersebut adalah siswa SMP dan SMA, belum ada yang meneliti siswa SD. Karena belum adanya penelitian yang membahas mengenai transisi yang terjadi pada masa SD kelas V dan SMP kelas VII, maka akan dilaksanakan penelitian mengenai berpikir aljabar siswa SD kelas $\mathrm{V}$ dan SMP kelas VII dengan cross-sectional design. Jenis penelitian ini dipilih karena penelitian dengan cross-sectional design tidak memerlukan terlalu banyak waktu. Metode ini memungkinkan penelitian dilakukan dalam waktu yang lebih singkat dengan kelompok sampel yang berbeda namun memiliki karakteristik yang sama (Cohen, Manion, \& Morrison, 2011).

Berdasarkan latar belakang dan kajian literatur di atas maka perumusan masalah adalah 1) Bagaimana kemampuan berpikir aljabar siswa SD kelas V?; 2) Bagaimana kemampuan berpikir aljabar siswa SMP kelas VII?; dan 3) Bagaimana perkembangan kemampuan berpikir aljabar siswa dari SD kelas V hingga SMP kelas VII?

Dari perumusan masalah maka tujuan penulisan adalah 1) mengetahui kemampuan berpikir aljabar siswa sekolah dasar; 2) mengetahui kemampuan berpikir aljabar siswa sekolah menengah; dan 3) mendeskripsikan perkembangan kemampuan berpikir aljabar siswa dari sekolah dasar hingga sekolah menengah.

\section{METODE}

Jenis penelitian ini merupakan cross-sectional study. Cross-sectional study merupakan salah satu jenis penelitian yang menghasilkan gambaran dari populasi pada titik waktu tertentu (Cohen, Manion, \& Morrison, 2011). Salah satu jenis penelitian cross-sectional study adalah cross-age study. Penelitian ini digunakan untuk mengamati perubahan dalam perkembangan mental dan pengetahuan siswa. Hal tersebut diperkuat oleh pernyataan Morgil dan Yörük (2006) bahwa jenis penelitian ini melibatkan halhal yang berkaitan dengan sifat dan tingkat perubahan dalam perkembangan fisik maupun intelektual sampel yang diambil secara tidak langsung.

Penelitian ini menggunakan quantitative descriptive approach. Penelitian ini dilaksanakan di tiga sekolah dasar dan tiga sekolah menengah 
pertama yang terletak Kota Yogyakarta dan dilaksanakan pada tahun 2017. Subjek penelitian ini adalah 77 siswa SD kelas V dari 3 sekolah yang berbeda dan 95 siswa SMP kelas VII dari 3 sekolah yang berbeda. Teknik penarikan sampel yang digunakan adalah teknik stratified purposive. Teknik tersebut merupakan gabungan dari stratified sampling (teknik sampling bertingkat) dan purposive sampling (teknik sampling bertujuan) dimana populasi dibagi menjadi beberapa kategori/strata dan kemudian beberapa sampel dipilih dengan pertimbangan tertentu.

Penentuan kategori untuk SMP berdasarkan perolehan nilai UN pada mata pelajaran matematika pada Penerimaan Peserta Didik Baru (PPDB) tahun ajaran 2016/2017, sedangkan penentuan kategori siswa SD dengan menggunakan perolehan nilai US/M mata pelajaran matematika tahun 2017. Pengelompokkan kategori SD dan SMP berdasarkan kategori nilai ujian nasional matematika yang terdapat dalam Permendikbud No. 5 Tahun 2015 (Kementerian Pendidikan dan Kebudayaan, 2015) yang disajikan pada Tabel 2.

Setelah dilakukan penentuan sekolah dalam setiap kategori, selanjutnya pengambilan subjek penelitian dilakukan dengan purposive sampling. Purposive sampling (teknik sampling bertujuan) adalah teknik dimana pengambilan subjek penelitian dilakukan dengan pertimbangan tertentu. Hal yang menjadi pertimbangan peneliti

Tabel 2 Kriteria Penentuan Kategori Sekolah

\begin{tabular}{ccc}
\hline Kategori & $\begin{array}{c}\text { Tingkat } \\
\text { Kompetensi } \\
\text { Lulusan }\end{array}$ & Kriteria \\
\hline A & Sangat Baik & $85<\overline{\mathrm{x}} \leq 100$ \\
B & Baik & $70<\overline{\mathrm{x}} \leq 85$ \\
C & Cukup & $55<\overline{\mathrm{x}} \leq 70$ \\
D & Kurang & $\overline{\mathrm{x}} \leq 55$ \\
\hline
\end{tabular}

dimana $\bar{x}$ adalah rata-rata nilai UN pada mata pelajaran matematika untuk penentuan kategori SMP dan rata-rata nilai US/M pada mata pelajaran matematika untuk kategori SD. dalam menentukan subjek penelitian adalah sebagai berikut.

1. Subjek penelitian memiliki standar deviasi maksimum yang bertujuan agar kemampuan partisipan yang diperoleh mempunyai perbedaan maksimum.

2. Ketersediaan narasumber yang terlibat dalam penelitian.

Tabel 3 adalah daftar sekolah dalam penelitian ini. Teknik pengumpulan data yang digunakan adalah teknik tes. Instrumen tes yang digunakan berupa soal berpikir aljabar yang berupa 6 soal uraian yang terdiri 3 kegiatan yaitu kegiatan generasional, transformasional, dan global meta-level. Dalam penelitian cross sectional yang telah dilakukan sebelumnya oleh Ültay dan Ültay (2010) dan Patton dan Santos (2012), instrumen tes yang digunakan sama. Dengan demikian, pada penelitian ini, instrumen tes yang digunakan siswa SD kelas V dan SMP kelas VII sama. Hal tersebut bertujuan agar dapat membandingkan kemampuan berpikir aljabar siswa SD kelas V dan SMP kelas VII.

Validasi instrumen tes dilakukan dengan uji validitas isi. Instrumen tes dikembangkan dengan membuat indikator kemampuan berpikir aljabar kemudian dikonsultasikan kepada expert judgment untuk diperiksa dan dievaluasi kesesuaian indikator dengan item yang dikembangkan. Selanjutnya dilakukan ujicoba, estimasi realibilitas tes kemampuan berpikir aljabar yang diperoleh adalah 0,677.

Tabel 3 Subjek Penelitian

\begin{tabular}{cccc}
\hline $\begin{array}{c}\text { Jenjang } \\
\text { Sekolah }\end{array}$ & Kategori & Kelas & $\begin{array}{c}\text { Jumlah } \\
\text { Siswa }\end{array}$ \\
\hline SD & B & VI A & 28 \\
& C & VI A & 26 \\
& D & VI & 23 \\
SMP & A & VII B & 31 \\
& B & VII D & 32 \\
& C & VII G & 32 \\
\hline
\end{tabular}


Teknik analisis data yang digunakan adalah analisis deskriptif. Berikut ini adalah langkahlangkah analisis data yang dilaksanakan.

1. Mengumpulkan dan mentabulasi data

2. Menggolongkan siswa-siswa yang memiliki kemampuan berpikir aljabar tinggi, sedang, dan rendah sesuai ketentuan seperti terlihat Tabel 4.

Tabel 4 Kriteria Kemampuan Berpikir

Aljabar Siswa (Azwar, 2012: 132)

\begin{tabular}{cc}
\hline Interval & Kriteria \\
\hline$X>M_{i}+S D_{i}$ & Tinggi \\
$M_{i}-S D_{i}<x \leq M_{i}+S D_{i}$ & Sedang \\
$x \leq M_{i}-S D_{i}$ & Rendah \\
\hline
\end{tabular}

dengan

$M_{i} \quad=$ Skor rata-rata ideal

$=\frac{1}{2}$ (skor tertinggi + skor terendah)

$S D_{i} \quad=$ Standar Deviasi

$=\frac{1}{6}$ (skor tertinggi - skor terendah)

Kemampuan berpikir aljabar secara umum dilihat berdasarkan skor rata-rata yang diperoleh setiap jenjang sekolah untuk keseluruhan soal. Instrumen tes terdiri dari 6 soal dengan nilai maksimum adalah 10 dan nilai minimumnya adalah 0 . Berdasarkan Tabel 4 diperoleh ketentuan sebagai berikut.

$\mathrm{M}_{\mathrm{i}} \quad=$ Skor rata-rata ideal

$=\frac{1}{2}(10+0)=5$

$\mathrm{SD}_{\mathrm{i}} \quad=$ Standar Deviasi

$$
=\frac{1}{6}(10-0)=1,6
$$

Dengan demikian, kriteria untuk kemampuan berpikir aljabar siswa untuk keseluruhan soal seperti terlihat pada Tabel 5 .

Tabel 5 Kriteria Kemampuan Berpikir Aljabar Siswa

\begin{tabular}{cc}
\hline Skor & Kriteria \\
\hline $\mathrm{X}>6,6$ & Tinggi \\
$3,4<\mathrm{X} \leq 6,6$ & Sedang \\
$\mathrm{X} \leq 3,4$ & Rendah
\end{tabular}

Skor rata-rata masing-masing tipe kegiatan yang diperoleh setiap jenjang dan kategori sekolah dihitung, kemudian menentukan kriteria skor sesuai dengan ketentuan pada Tabel 5. Hal ini digunakan untuk melihat kecenderungan kemampuan siswa dalam menyelesaikan setiap soal yang diberikan.

3. Menyajikan data-data yang telah dikumpulkan dalam bentuk uraian singkat, tabel, diagram, hubungan antarkategori, dan sejenisnya agar mudah dipahami.

4. Menarik kesimpulan berdasarkan analisis terhadap data-data yang telah dikumpulkan melalui tes kemampuan berpikir aljabar mengenai persentase kemampuan siswa terhadap siswa.

\section{HASIL DAN PEMBAHASAN \\ Kinerja Siswa Sekolah Dasar}

Kinerja siswa sekolah dasar kelas V disajikan dalam Tabel 6 . Tabel 6 menunjukkan bahwa siswa dengan strata $B$ memiliki rata-rata yang lebih tinggi dibanding strata lainnya yaitu 5,7 . Rata-rata ketiganya masih termasuk dalam kriteria sedang. Berikut ini disajikan data kinerja siswa SD berdasarkan tipe kegiatan berpikir aljabar.

Gambar 1 menunjukkan bahwa siswa strata $B$ mempunyai total skor dan rata-rata yang lebih tinggi dari strata lainnya. Berbeda dengan strata B, strata C, dan D mempunyai skor total dan rata-rata yang hampir sama. Total skor dan rata-rata hasil jawaban siswa dalam kegiatan generasional dan global meta-level berada dalam

Tabel 6 Persentase Hasil Jawaban Siswa SD kelas $\mathrm{V}$

\begin{tabular}{cccc}
\hline $\begin{array}{c}\text { Kategori } \\
\text { Sekolah }\end{array}$ & $\begin{array}{c}\text { Total } \\
\text { Skor }\end{array}$ & $\begin{array}{c}\text { Skor Rata- } \\
\text { Rata }\end{array}$ & Kriteria \\
\hline B $(n=28)$ & 158,3 & 5,7 & Sedang \\
C $(n=26)$ & 103,1 & 3,9 & Sedang \\
D $(n=23)$ & 96,1 & 4,1 & Sedang \\
Keseluruhan & 357,5 & 4,6 & Sedang \\
\hline
\end{tabular}




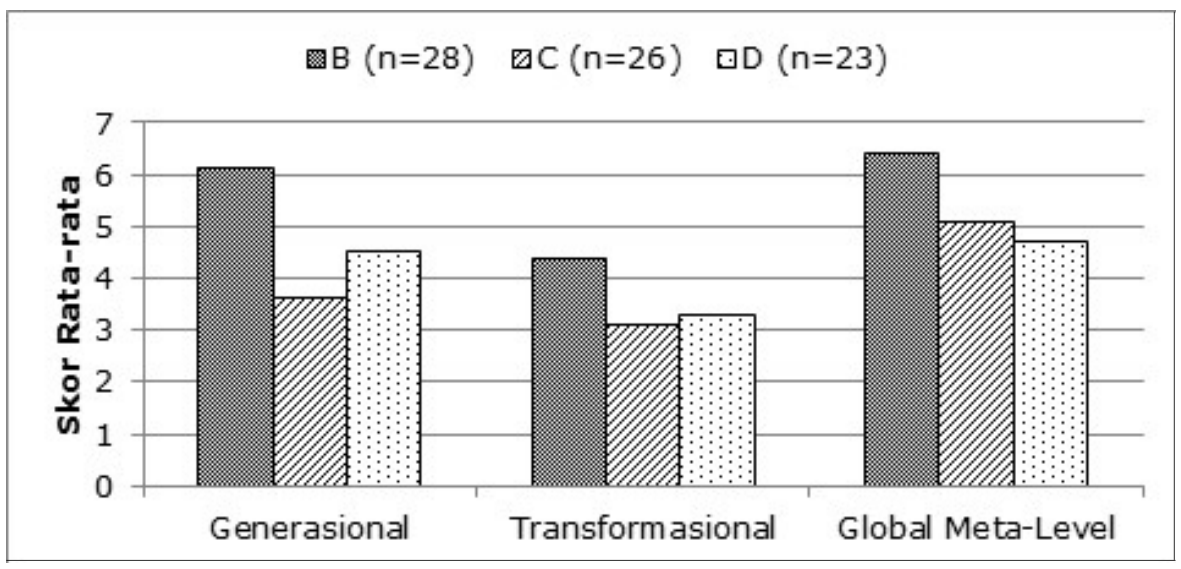

Gambar 1 Perbandingan Rata-rata Skor Siswa SD berdasarkan Tipe Soal

kriteria sedang, kecuali pada kegiatan transformasional dimana sekolah strata $\mathrm{C}$ dan D berada dalam kriteria rendah. Dengan demikian, siswa memiliki rata-rata skor tertinggi pada kegiatan global meta-level dan rata-rata skor terendah pada kegiatan transformasional.

\section{Kinerja Siswa Sekolah Menengah Pertama}

Kinerja siswa sekolah menengah pertama kelas VII disajikan dalam Tabel 7. Tabel 7 menunjukkan bahwa siswa dengan strata A memiliki ratarata yang lebih tinggi dibanding strata lainnya yaitu 7,1 dan berada dalam kriteria tinggi. Berbeda dengan sekolah strata $B$ dan $C$ yang berada dalam strata sedang. Gambar 2 menyajikan data kinerja siswa SMP berdasarkan tipe kegiatan berpikir aljabar. Gambar 2 menunjukkan bahwa sekolah strata A memiliki total skor dan rata-rata yang lebih tinggi dibanding sekolah lainnya dalam semua kegiatan berpikir aljabar. Sedangkan total skor dan ratarata sekolah strata B sedikit lebih tinggi dibanding sekolah strata C, namun masih dalam kriteria sedang. Rata-rata skor tertinggi siswa SMP kelas VII adalah pada kegiatan generasional, sedangkan rata-rata skor terendah pada kegiatan transformasional.

\section{Perbandingan Kemampuan Berpikir}

\section{Aljabar Siswa SD kelas V dan SMP kelas VII}

Tes kemampuan berpikir aljabar terdiri dari 6 soal uraian. Tabel 8 adalah hasil tes kemampuan berpikir aljabar secara umum. Tabel 8 menunjukkan bahwa sebagian besar siswa SD kelas $\mathrm{V}$ memiliki kemampuan berpikir aljabar berada dalam kriteria sedang sejumlah $82 \%$ siswa. Sebagian besar siswa SMP kelas VII memiliki kemampuan berpikir aljabar pada kriteria sedang, yaitu sebesar 53\% siswa, namun terdapat 44\% siswa yang memiliki kemampuan berpikir aljabar yang berada di kriteria tinggi. Untuk rata-rata skor yang diperoleh siswa berdasarkan tipe kegiatan disajikan pada Tabel 8.

Tabel 7 Persentase Hasil Jawaban Siswa SMP

\begin{tabular}{cccc}
\hline Kategori Sekolah & Total Skor & Skor Rata-Rata & Kriteria \\
\hline A $(n=31)$ & 219,8 & 7,1 & Tinggi \\
B $(n=32)$ & 194,17 & 6,1 & Sedang \\
C $(n=32)$ & 173,6 & 5,4 & Sedang \\
Keseluruhan & 587,57 & 6,2 & Sedang \\
\hline
\end{tabular}


Tabel 8 Hasil Tes Kemampuan Berpikir Aljabar Secara Umum

\begin{tabular}{ccccc}
\hline $\begin{array}{c}\text { Kemampuan Berpikir } \\
\text { Aljabar Siswa }\end{array}$ & \multicolumn{2}{c}{ SD kelas V } & \multicolumn{2}{c}{ SMP kelas VII } \\
Jumlah & $(\%)$ & Jumlah & $(\%)$ \\
\hline Tinggi & 6 & 8 & 42 & 44 \\
Sedang & 63 & 82 & 50 & 53 \\
Rendah & 8 & 10 & 3 & 3
\end{tabular}

Tabel 9 dan Gambar 3 menunjukkan bahwa untuk semua aspek dalam berpikir aljabar siswa SD kelas $\mathrm{V}$ dan SMP kelas VII berada dalam kriteria sedang dengan rata-rata berturut-turut 4,6 dan 6,3 . Rata-rata tertinggi untuk siswa SD kelas $V$ adalah pada kegiatan global metalevel, sedangkan untuk siswa SMP kelas VII pada kegiatan generasional. Di sisi lain, rata-rata skor terendah yang diperoleh untuk jenjang SD kelas V dan SMP kelas VII adalah pada kegiatan transformasional.

\section{Kemampuan Berpikir Aljabar Siswa Berdasarkan Tipe Kegiatan Kegiatan Generasional}

Soal Kegiatan Generasional Nomor 1 bertujuan untuk mengetahui kemampuan siswa dalam menggeneralisasi pernyataan yang muncul dari pola-pola geometri atau barisan bilangan, dan pernyataan dari aturan yang berkaitan dengan numerik. Soal Kegiatan Generasional nomor 1 ditunjukkan oleh Gambar 4.

Selanjutnya setelah data dianalisis, diperoleh data perbandingan hasil yang diperoleh setiap jenjang sekolah yang disajikan pada Tabel 10. Tabel 10 menunjukkan perbedaan yang

Tabel 9 Hasil Tes Kemampuan Berpikir Aljabar Berdasarkan Tipe Kegiatan

\begin{tabular}{|c|c|c|c|c|c|c|c|}
\hline \multirow{2}{*}{\multicolumn{2}{|c|}{ Kegiatan }} & \multicolumn{3}{|c|}{ SD kelas V } & \multicolumn{3}{|c|}{ SMP kelas VII } \\
\hline & & TS & $\overline{\mathrm{x}}$ & Kriteria & TS & $\overline{\mathrm{x}}$ & Kriteria \\
\hline & Generasional & 370,0 & 4,8 & Sedang & 684,2 & 7,2 & Tinggi \\
\hline & ransformasional & 280,8 & 3,6 & Sedang & 454,2 & 4,8 & Sedang \\
\hline & lobal Meta-Level & 421,7 & 5,4 & Sedang & 624,2 & 6,6 & Sedang \\
\hline & Keseluruhan & 1072,5 & 4,6 & Sedang & 1762,6 & 6,3 & Sedang \\
\hline \multicolumn{3}{|c|}{ 四 Generasional } & \multicolumn{2}{|c|}{ Utransformasional } & \multicolumn{3}{|c|}{ 口Global Meta-Level } \\
\hline \multicolumn{8}{|l|}{8} \\
\hline \multirow{2}{*}{\multicolumn{8}{|c|}{6}} \\
\hline & & & & & & & \\
\hline \multirow{2}{*}{4} & \multicolumn{7}{|c|}{5} \\
\hline \multirow{2}{*}{\multicolumn{8}{|c|}{$\begin{array}{l}3 \\
2\end{array}$}} \\
\hline & & & & & & & \\
\hline 1 & & & & & & & \\
\hline & & kelas V & & & & S & \\
\hline
\end{tabular}

Gambar 3 Perbandingan Rata-rata Skor Tes Siswa SMP kelas VII berdasarkan Tipe Kegiatan 
1. Perhatikan susunan bangun (1), (2), (3), (4) di bawah ini.

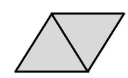

(1)

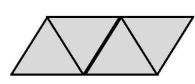

(2)

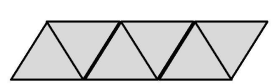

(3)

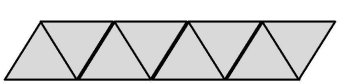

(4)

a. Berapa banyak segitiga yang dibutuhkan untuk menyusun bangun ke-10?

b. Susunan bangun ke berapa yang membutuhkan segitiga sebanyak 30 ?

c. Berapa banyak segitiga yang dibutuhkan untuk menyusun bangun ke- $n$ ?

Gambar 4 Soal Kegiatan Generasional Nomor 1

Tabel 10 Perbandingan Kemampuan Berpikir Aljabar pada Soal Nomor 1 Kegiatan Generasional

\begin{tabular}{ccccccccc}
\hline Jenjang & \multicolumn{4}{c}{ SD } & \multicolumn{5}{c}{ SMP } \\
Nomor Soal & 1a (\%) & 1b (\%) & 1c (\%) & $1(\%)$ & $1 \mathrm{a}(\%)$ & $1 \mathrm{~b}(\%)$ & $1 \mathrm{c}(\%)$ & $1(\%)$ \\
\hline Benar & 37 & 30 & 8 & 25 & 86 & 82 & 33 & 67 \\
Salah & 63 & 70 & 92 & 75 & 14 & 18 & 67 & 33 \\
Symbolic & 0 & 0 & 8 & 3 & 2 & 1 & 30 & 11 \\
Non-Symbolic & 100 & 100 & 92 & 97 & 98 & 99 & 70 & 89 \\
\hline
\end{tabular}

cukup besar antara siswa SD kelas V dan SMP kelas VII. Terdapat perbedaan jawaban benar dan penggunaan simbol siswa SD kelas $\mathrm{V}$ yang berturut-turut hanya $25 \%$ dan $3 \%$ yang memiliki perbedaan yang cukup besar dengan siswa SMP kelas VII dengan persentase siswa yang menjawab benar dan menggunakan simbol mencapai $67 \%$ dan $11 \%$. Siswa SD kelas $V$ yang dapat menggeneralisasikan pola ke-n hanya $8 \%$ sedangkan siswa SMP kelas VII hanya 30\%. Penggunaan simbol baik siswa SD kelas $\mathrm{V}$ maupun siswa SMP kelas VII masih rendah, artinya siswa masih belum bisa menggeneralisasikan suatu pola dengan menggunakan simbol.

Untuk SMP kelas VII, diketahui bahwa lebih dari $80 \%$ siswa mampu menjawab nomor 1a dan 1b dengan benar. Siswa mampu menjawab dengan benar tanpa menggunakan aljabar. Dengan demikian, rata-rata $84 \%$ telah mampu memprediksikan pola yang diberikan jika diberikan suatu bilangan tertentu. Dengan demikian, ratarata hanya $30 \%$ yang mampu menuliskan pola $\mathrm{ke}{ }_{n}$ dari pola yang diberikan. Jadi, siswa SMP sudah berada pada level operasional formal dimana siswa dapat menggeneralisasikan pola dengan baik.

Soal Kegiatan Generasional Nomor 2 bertujuan untuk mengetahui kemampuan siswa dalam pembentukan pernyataan dan persamaan, termasuk pembentukan persamaan yang memuat suatu kuantitas yang tidak diketahui yang merepresentasikan situasi masalah. Soal Kegiatan Generasional nomor 2 ditunjukkan pada Gambar 5.

Selanjutnya setelah data dianalisis, diperoleh data perbandingan hasil yang diperoleh setiap jenjang sekolah yang disajikan pada Tabel 11. Tabel 11 menunjukkan perbedaan yang cukup besar antara siswa SD kelas V dan SMP kelas VII. Terdapat perbedaan jawaban benar dan penggunaan simbol siswa SD kelas $V$ yang berturut-turut hanya $0 \%$ dan $18 \%$ yang memiliki perbedaan yang cukup besar dengan siswa SMP kelas VII dengan persentase siswa yang menjawab benar dan menggunakan simbol 
2. Perhatikan pernyataan di bawah ini.

a. Uang saku yang diperoleh Eko dua kali lebih banyak dari uang saku Dwi. Jika uang Eko adalah $m$, maka tentukan uang saku Dwi.

b. Suhu di Kota Pontianak $10^{\circ}$ lebih besar dari dibandingkan suhu di Kota Yogyakarta. Jika suhu di Kota Pontianak adalah $h$, maka tentukan suhu di kota Pontianak.

c. Pak Slamet memiliki satu meter kain. Jika untuk keperluan tertentu dipotong $y \mathrm{~cm}$, maka tentukan sisa kain yang dimiliki Pak Slamet.

Gambar 5 Soal Kegiatan Generasional Nomor 2

Tabel 11 Perbandingan Kemampuan Berpikir Aljabar pada Soal Nomor 2 Kegiatan Generasional

\begin{tabular}{ccccccccc}
\hline Jenjang & \multicolumn{9}{c}{ SD } & \multicolumn{5}{c}{ SMP } \\
Nomor Soal & $2 \mathrm{a}(\%)$ & $2 \mathrm{~b}(\%)$ & $2 \mathrm{c}(\%)$ & $2(\%)$ & $2 \mathrm{a}(\%)$ & $2 \mathrm{~b}(\%)$ & $2 \mathrm{c}(\%)$ & $2(\%)$ \\
\hline Benar & 0 & 0 & 0 & 0 & 28 & 37 & 38 & 34 \\
Salah & 100 & 100 & 100 & 100 & 72 & 63 & 62 & 66 \\
Symbolic & 24 & 24 & 8 & 18 & 79 & 77 & 68 & 75 \\
Non-Symbolic & 76 & 76 & 96 & 83 & 46 & 37 & 30 & 38 \\
\hline
\end{tabular}

mencapai $34 \%$ dan $75 \%$. Terdapat perbedaan penggunaan simbol baik siswa SD kelas $\mathrm{V}$ dan siswa SMP kelas VII, penggunaan simbol siswa SMP kelas VII cukup tinggi, namun hanya $18 \%$ siswa yang dapat menjawab dengan benar, artinya siswa dapat menggunakan simbol tetapi belum dapat membuat persamaan sesuai dengan situasi atau permasalahan yang diberikan.

\section{Kegiatan Transformasional}

Soal Kegiatan Transformasional Nomor 3 bertujuan untuk siswa dapat menggunakan representasi untuk memanipulasi pernyataan. Representasi yang digunakan berupa angka dan simbol. Soal Kegiatan Transfomasional nomor 3 ditunjukkan pada Gambar 6.

Selanjutnya setelah data dianalisis, diperoleh data perbandingan hasil yang diperoleh setiap jenjang sekolah yang disajikan pada Tabel

3. Dengan mengikuti langkah-langkah berikut secara berurutan, isilah tabel di bawah ini.

\begin{tabular}{|l|l|c|c|}
\hline No. & Langkah-langkah & Bilangan & Simbol \\
\hline 1 & Bilangan & 100 & $n$ \\
\hline 2 & Kalikan dengan 2 & & \\
\hline Selanjutnya, lakukan operasi berikut ini pada hasil di atas. \\
\hline 3 & Tambahkan 2 & \\
\hline Selanjutnya, lakukan operasi berikut ini pada hasil di atas. \\
\hline 4 & Bagi dengan 2 & \\
\hline Selanjutnya, lakukan operasi berikut ini pada hasil di atas. \\
\hline 5 & Kurangi 1 & \\
\hline
\end{tabular}

Gambar 6 Soal Kegiatan Transformasional Nomor 3 
12. Tabel 12 menunjukkan terlihat perbedaan yang cukup besar antara siswa SD kelas $V$ dan SMP kelas VII. Terdapat perbedaan jawaban benar dan penggunaan simbol siswa SD kelas $\mathrm{V}$ yang berturut-turut hanya 0\% dan 19\% yang memiliki perbedaan yang cukup besar dengan siswa SMP kelas VII dengan persentase siswa yang menjawab benar dan menggunakan simbol mencapai $21 \%$ dan $72 \%$. Terdapat perbedaan penggunaan simbol baik siswa SD kelas $V$ dan siswa SMP kelas VII, penggunaan simbol siswa SMP kelas VII cukup tinggi, namun hanya $20 \%$ siswa yang dapat menjawab dengan benar, artinya siswa belum dapat mengoperasikan variabel dengan benar. Untuk siswa SD, 19\% siswa mampu mengoperasikan variabel,

Tabel 12 Perbandingan Kemampuan Berpikir Aljabar pada Soal Nomor 3 Kegiatan Transformasional

\begin{tabular}{ccc}
\hline Jenjang & SD & SMP \\
Nomor Soal & $3(\%)$ & $3(\%)$ \\
\hline Benar & 0 & 21 \\
Salah & 100 & 79 \\
Symbolic & 19 & 72 \\
Non-Symbolic & 78 & 28 \\
\hline
\end{tabular}

meskipun masih menunjukkan beberapa kesalahan dalam pengoperasiannya, siswa mampu menunjukkan operasi perkalian dengan benar tetapi belum dapat melakukan operasi penjumlahan, pengurangan, dan pembagian dengan benar. Untuk siswa SMP, diketahui bahwa $21 \%$ siswa SMP dapat mengoperasikan variabel dengan benar, sedangkan $50 \%$ siswa melakukan kesalahan pada mengoperasian variabel.

Soal Kegiatan Transformasional Nomor 4 bertujuan siswa dapat menentukan nilai variabel yang nilainya belum diketahui. Soal Kegiatan Transfomasional nomor 4 ditunjukkan pada Gambar 7.

Selanjutnya setelah data dianalisis, diperoleh data perbandingan hasil yang diperoleh setiap jenjang sekolah yang disajikan pada Tabel 13. Tabel 13 menunjukkan bahwa terdapat perbedaan jawaban benar dan penggunaan simbol siswa SD kelas $\mathrm{V}$ yang berturut-turut hanya $7 \%$ dan $0 \%$ yang memiliki perbedaan yang cukup besar dengan siswa SMP kelas VII dengan persentase siswa yang menjawab benar dan menggunakan simbol mencapai $24 \%$ dan $13 \%$. Persentase siswa yang dapat menentukan nilai variabel yang nilainya belum diketahui lebih

4. Perhatikan pernyataan di bawah ini.

a. Ani mempunyai satu kotak pensil, Budi mempunyai 12 pensil. Pensilpensil tersebut dimasukkan ke dalam dua buah kotak yang sama dan masih tersisa 2 pensil. Berapakah jumlah pensil dalam satu kotak?
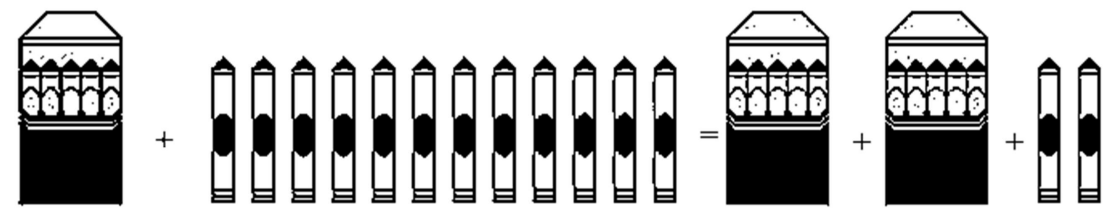

b.

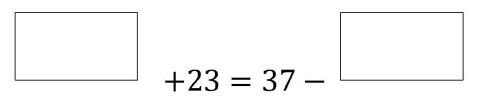

Tentukan nilai yang memenuhi bagian yang kosong di atas dengan bilangan yang sama

Gambar 7 Soal Kegiatan Transformasional Nomor 4 
Tabel 13 Perbandingan Kemampuan Berpikir Aljabar pada Soal Nomor 4 Kegiatan Transformasional

\begin{tabular}{ccccccc}
\hline Jenjang & \multicolumn{3}{c}{ SD } & & SMP & \\
Nomor Soal & $4 \mathrm{a}(\%)$ & $4 \mathrm{~b}(\%)$ & $4(\%)$ & $4 \mathrm{a}(\%)$ & $4 \mathrm{~b}(\%)$ & $4(\%)$ \\
\hline Benar & 13 & 0 & 7 & 16 & 33 & 24 \\
Salah & 87 & 100 & 93 & 84 & 67 & 76 \\
Symbolic & 0 & 0 & 0 & 15 & 12 & 13 \\
Non-Symbolic & 100 & 100 & 100 & 72 & 62 & 67 \\
\hline
\end{tabular}

besar dibanding penggunaan simbol, artinya siswa dapat menjawab dengan benar tanpa menggunakan simbol.

\section{Kegiatan Global Meta-Level}

Soal Kegiatan Global Meta-Level Nomor 5 bertujuan siswa dapat memecahkan masalah terkait dengan kehidupan sehari-hari. Soal Kegiatan Global Meta-Level nomor 5 ditunjukkan pada Gambar 8.
Selanjutnya setelah data dianalisis, diperoleh data perbandingan hasil yang diperoleh setiap jenjang sekolah yang disajikan pada Tabel 14. Tabel 14 menunjukkan bahwa terdapat perbedaan jawaban benar dan penggunaan simbol siswa SD kelas $\mathrm{V}$ yang berturut-turut hanya $21 \%$ dan $0 \%$ yang memiliki perbedaan yang cukup besar dengan siswa SMP kelas VII dengan persentase siswa yang menjawab benar dan menggunakan simbol mencapai $51 \%$ dan

5. Selesaikan permasalahan berikut ini.

a. Harga 6 LKS Matematika adalah Rp30.000,00. Jika Bu Guru ingin membeli LKS untuk 27 siswa. berapakah yang harus ia bayar?

b. Susan dan Mira bermain tebak-tebakan. Susan mempunyai dua buah kantong berisi kelereng dan meminta Mira menebak banyaknya kelereng dalam masing-masing kantong. Susan memberikan dua petunjuk yaitu salah satu kantong memuat 6 kelereng lebih banyak dibanding kantong yang lain dan jumlah kelereng seluruhnya adalah 24. Dapatkah kalian membantu Mira untuk menebak isi kantong tersebut? Berapakah banyaknya kelereng pada masing-masing kantong?

c. Sebuah Toko Donat menjual dua paket Donat yaitu paket A berisi 4 donat sedangkan paket B berisi 6 donat. Toko tersebut menerima pesanan 10 Paket Donat. Namun, salah satu pegawai toko menghilangkan catatan pemesanannya. Jika donat yang telah dibuat untuk memenuhi pesanan tersebut berjumlah 50, berapakah banyaknya pesanan Paket A dan Paket $\mathrm{B}$ ?

Gambar 8 Soal Kegiatan Global Meta-Level Nomor 5

Tabel 14 Perbandingan Kemampuan Berpikir Aljabar pada Soal Nomor 5 Kegiatan Global Meta-Level

\begin{tabular}{ccccccccc}
\hline Jenjang & \multicolumn{4}{c}{ SD } & \multicolumn{5}{c}{ SMP } \\
Nomor Soal & $5 \mathrm{a}(\%)$ & $5 \mathrm{~b}(\%)$ & $5 \mathrm{c}(\%)$ & $5(\%)$ & $5 \mathrm{a}(\%)$ & $5 \mathrm{~b}(\%)$ & $5 \mathrm{c}(\%)$ & $5(\%)$ \\
\hline Benar & 60 & 2 & 1 & 21 & 83 & 38 & 33 & 51 \\
Salah & 40 & 98 & 99 & 79 & 17 & 62 & 67 & 49 \\
Symbolic & 0 & 0 & 0 & 0 & 7 & 6 & 5 & 6 \\
Non-Symbolic & 100 & 100 & 100 & 100 & 93 & 94 & 95 & 74 \\
\hline
\end{tabular}


6. Perhatikan gambar di bawah ini.

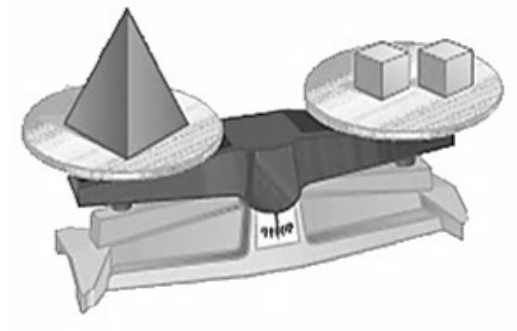

(i)

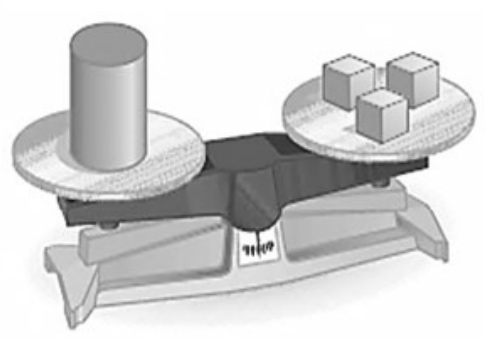

(ii)

Tentukan apakah setiap pernyataan benar atau salah. Berilah alasannya.

a. Satu piramida dan empat kubus seimbang dengan dua tabung.

b. Satu tabung dan dua kubus seimbang dengan dua piramida.

Gambar 9 Soal Kegiatan Global Meta-Level Nomor 6

6\%. Persentase siswa yang menjawab benar lebih besar dibanding penggunaan simbol, artinya siswa dapat menjawab dengan benar tanpa menggunakan simbol. Jad, siswa SD dapat menyelesaikan masalah sederhana tetapi belum dapat menyelesaikan masalah yang lebih kompleks. Penyelesaian masalah tersebut pun $100 \%$ tanpa menggunakan simbol. Jadi, dapat disimpulkan bahwa siswa SD kelas $\mathrm{V}$ mampu menyelesaikan masalah matematika sederhana tanpa menggunakan simbol. Sedangkan, untuk siswa SMP kelas VII mampu menyelesaikan masalah matematika sederhana dengan menggunakan simbol tetapi sedikit siswa menyelesaikan masalah yang lebih kompleks.

Soal Kegiatan Global-Meta Level nomor 6 bertujuan siswa dapat menganalisis suatu pernyataan untuk membuktikan benar atau tidaknya suatu pernyataan. Soal Kegiatan Global Meta-Level nomor 6 ditunjukkan pada Gambar 9.

Selanjutnya setelah data dianalisis, diperoleh data perbandingan hasil yang diperoleh setiap jenjang sekolah yang disajikan pada Tabel 15. Tabel 15 menunjukkan bahwa terdapat perbedaan jawaban benar dan penggunaan simbol siswa SD kelas $\mathrm{V}$ yang berturut-turut hanya $23 \%$ dan $0 \%$ yang memiliki perbedaan yang cukup besar dengan siswa SMP kelas VII dengan persentase siswa yang menjawab benar dan menggunakan simbol mencapai $42 \%$ dan $17 \%$. Persentase siswa yang menjawab benar lebih besar dibanding penggunaan simbol, artinya siswa dapat menentukan suatu pernyataan benar atau salah tanpa menggunakan simbol.

Tabel 15 Perbandingan Kemampuan Berpikir Aljabar pada Soal Nomor 6 Kegiatan Global Meta-Level

\begin{tabular}{ccccccc}
\hline Jenjang & \multicolumn{3}{c}{ SD } & \multicolumn{3}{c}{ SMP } \\
Nomor Soal & $6 \mathrm{a}(\%)$ & $6 \mathrm{~b}(\%)$ & $6(\%)$ & $6 \mathrm{a}(\%)$ & $6 \mathrm{~b}(\%)$ & $6(\%)$ \\
\hline Benar & 24 & 21 & 23 & 40 & 44 & 42 \\
Salah & 76 & 69 & 72 & 60 & 53 & 57 \\
Symbolic & 0 & 0 & 0 & 20 & 13 & 17 \\
Non-Symbolic & 100 & 100 & 100 & 81 & 79 & 80 \\
\hline
\end{tabular}




\section{Pembahasan}

Siswa SD kelas $V$ berada pada awal masa transisi dari berpikir aritmatika ke berpikir aljabar. Kemampuan berpikir aljabar siswa SD kelas $\mathrm{V}$ berada dalam kriteria sedang dengan skor ratarata tes kemampuan berpikir aljabar siswa sebesar 4,6. Sekolah SD kategori B, C, dan D memiliki rata-rata skor tes kemampuan berpikir aljabar siswa berturut-turut yaitu 5,7; 3,9; dan 4,1 yang berada dalam kategori sedang. Hal ini disebabkan karena berpikir aljabar telah diperkenalkan di sekolah dasar tetapi bukan berpikir aljabar secara formal (Puspita, Kaniawati, \& Suwarma, 2017). Selain itu, Tabel 6 menunjukkan bahwa terdapat perbedaan kemampuan yang signifikan antara sekolah yang berkategori B, C, maupun D. Siswa sekolah B memiliki rata-rata skor tes berpikir aljabar yang jauh lebih tinggi dibandingkan dengan sekolah lainnya. Hal ini disebabkan karena siswa sekolah kategori B telah diperkenalkan mengenai pengunaan simbol sehingga siswa dapat menyelesaikan masalah-masalah yang diberikan.

Disisi lain, pada Gambar 1, siswa SD memiliki rata-rata skor tertinggi pada kegiatan global meta-level. Hal ini disebabkan karena berpikir aljabar yang dipelajari hanya berkaitan dengan dasar-dasar untuk berpikir secara aljabar seperti memecahkan masalah (Puspita, Kaniawati, \& Suwarma, 2017). Berbeda dengan kegiatan transformasional, siswa memperoleh rata-rata skor kemampuan berpikir aljabar yang paling rendah dibandingkan dengan kegiatan lainnya. Hal ini disebabkan karena pada tingkat sekolah dasar, variabel atau bagian yang diketahui atau tidak diketahui tidak dilambangkan dalam bentuk huruf, tetapi dilambangkan dengan gambar atau titik-titik (Puspita, Kaniawati, \& Suwarma, 2017). Pada dasarnya, berpikir aljabar telah diperkenalkan tetapi bukan berpikir aljabar secara formal dan hanya berkaitan dengan dasar-dasar untuk berpikir secara aljabar terutama dalam memecahkan masalah sederhana.
Berbeda dengan siswa SD, Siswa SMP kelas VII berada pada akhir masa transisi dari berpikir aritmatika ke berpikir aljabar. Berdasarkan Tabel 7, kemampuan berpikir aljabar siswa SMP kelas VII berada dalam kriteria sedang dengan skor rata-rata 6,2. Siswa SMP terutama kelas VII telah diperkenalkan aljabar sehingga seharusnya siswa mampu menyelesaikan soal-soal berkaitan dengan aljabar. Sekolah SMP kategori A, B, dan $C$ memiliki rata-rata skor tes kemampuan berpikir aljabar siswa berturut-turut yaitu 7,1; 6,1; dan 5,4 . Rata-rata skor siswa sekolah kategori A berada dalam kriteria tinggi, sedangkan yang lainnya pada kriteria sedang.

Selain itu, Gambar 2 menunjukkan bahwa pada kegiatan generasional, rata-rata skor yang diperoleh siswa lebih tinggi dibandingkan kegiatan lainnya. Kegiatan ini merupakan bagian penting dalam berpikir aljabar. Menurut Mason, Graham, \& Johnston-Wilder (2005) setiap siswa yang memulai sekolah telah menunjukkan kemampuan untuk menggeneralisasikan dan mengabstraksikan kasus-kasus tertentu. Siswa SMP berada pada tahap operasional formal, maka pada tahap ini, siswa dapat berpikir secara lebih abstrak, idealis, dan cara-cara yang logis (Santrock, 2011) dan dapat memanfaatkan logika untuk menyelesaikan masalah (Feldman, 2011).

Untuk siswa SMP, pada kegiatan transformasional siswa di setiap kategori sekolah memperoleh rata-rata skor yang lebih rendah dibanding kegiatan lainnya. Kegiatan transformasional berhubungan dengan pengoperasian variabel untuk mempertahankan kesetaraan. Dalam kegiatan ini, siswa mengeluarkan (detach) variabel saat melakukan operasi bentuk aljabar (Drijvers, Goddijn, \& Kindt, 2011). Oleh karena itu, siswa SMP memiliki rata-rata skor kegiatan transformasional yang paling rendah dibanding kegiatan lainnya. Hal ini disebabkan berpikir aljabar telah diperkenalkan secara formal di SMP kelas VII dan berada dalam tahapan berpikir operasional formal dimana siswa sudah dapat 
berpikir secara abstrak dan logis.

Terdapat perbedaan kemampuan berpikir aljabar siswa SD kelas V dan siswa SMP kelas VII yang ditunjukkan pada Tabel 9. Siswa SD memiliki rata-rata skor tertinggi pada kegiatan global meta-level, sedangkan siswa SMP pada kegiatan generasional. Hal ini karena pada saat SD, berpikir aljabar yang diperkenalkan hanya berkaitan dengan dasar-dasar untuk berpikir secara aljabar seperti memecahkan masalah (Puspita, Kaniawati, \& Suwarma, 2017). Sedangkan pada masa SMP kelas VII, siswa telah mulai diperkenalkan dengan aljabar secara formal, selain itu, siswa berada dalam tahap operasional formal sehingga siswa berpikir secara lebih abstrak, idealis, dan cara-cara yang logis (Santrock, 2011). Oleh karena itu, pada kegiatan ini siswa SMP yang sudah berada pada level operasional formal sudah dapat menggeneralisasikan pola dengan baik.

Disisi lain, Tabel 8 menunjukkan sebaran kemampuan berpikir aljabar siswa SD kelas $\mathrm{V}$ dan SMP kelas VII. Sebagian besar siswa SD memiliki kemampuan berpikir aljabar dengan kriteria sedang, yaitu sebesar $82 \%$ siswa. Sementara itu, sebagian besar siswa SMP memiliki kemampuan berpikir aljabar dengan kriteria sedang dan tinggi, yaitu sebesar 53\% dan 44\%. Menurut Hidayanto (2014), siswa kelas V sampai dengan kelas VII mengalami suatu transisi proses berpikir dari berpikir aritmatika menuju berpikir aljabar secara bertahap, mulai dari kasus sederhana sampai dengan kasus yang lebih kompleks. Siswa kelas $\mathrm{V}$ hanya mampu menyelesaikan kasus-kasus sederhana, sedangkan siswa SMP kelas VII sudah mampu menyelesaikan kasus yang lebih kompleks.

Terdapat perbedaan persentase siswa dalam menjawab dengan benar soal tes kemampuan berpikir aljabar yang diberikan yang dipengaruhi oleh materi yang telah diperoleh siswa. Siswa SMP telah memperoleh materi aljabar secara formal sedangkan siswa SD belum diperkenalkan secara formal. Oleh karena itu, kemampuan siswa SD dalam menyelesaikan permasalahan aljabar masih dalam kategori sedang tidak jauh berbeda dengan siswa SMP.

\section{SIMPULAN DAN SARAN \\ Simpulan}

SD kelas $\mathrm{V}$ berada dalam awal masa transisi berpikir aljabar. Kemampuan berpikir aljabar siswa SD kelas $V$ berada dalam kriteria sedang dengan rata-rata skor tertinggi pada kegiatan global meta-level karena berpikir aljabar telah diperkenalkan di sekolah dasar, sedangkan ratarata terendah pada kegiatan transformasional.

Siswa SMP kelas VII berada pada akhir masa transisi. Kemampuan berpikir aljabar siswa SMP kelas VII berada dalam kriteria sedang. Siswa SMP kelas VII memiliki rata-rata skor tertinggi pada kegiatan generasional dan terendah pada kegiatan transformasional.

Kemampuan berpikir aljabar siswa berkembang seiring berjalannya waktu. Siswa SD kelas $V$ sampai dengan SMP kelas VII mengalami suatu transisi proses berpikir dari berpikir aritmatika menuju berpikir aljabar secara bertahap, mulai dari kasus sederhana sampai dengan kasus yang lebih kompleks. Hal ini dipengaruhi oleh materi yang telah diperoleh siswa. Siswa SMP telah memperoleh materi aljabar secara formal sedangkan siswa SD belum diperkenalkan secara formal.

\section{Saran}

Berdasarkan simpulan di atas, disarankan agar guru dapat memasukkan materi berpikir aljabar (algebraic thinking) dalam pembelajaran yang diberikan, dimana siswa lebih awal belajar aljabar secara formal. Dengan demikian, siswa di Indonesia memiliki kemampuan berpikir aljabar yang tinggi dan tidak tertinggal dari negara yang lain karena berpikir aljabar merupakan elemen mendasar dari berpikir matematika dan penalaran matematika. Selain itu, mengintegrasikan berpikir aljabar pada tingkat sekolah dasar dan menengah memberikan alternatif yang mem- 
bangun pengembangan konsep matematika secara kompleks dan mendalam pada penga-laman belajar siswa lebih dini. Disisi lain, perlu adanya pengembangan proses pembelajaran berupa penyusunan perangkat pembelajaran dan bahan ajar yang dapat meningkatkan kemam-puan berpikir aljabar siswa di semua jenjang sekolah terutama jenjang dimana siswa mengalami transisi dari berpikir aritmatika menuju berpikir aljabar.

\section{PUSTAKA ACUAN}

Azwar, S. (2012). Tes prestasi: Fungsi dan pengembangan pengukuran prestasi belajar. Yogyakarta: Pustaka Belajar.

Britt, M. S., \& Irwin, K. C. (2008). Algebraic thinking with and without algebraic representation: A three-year longitudinal study. ZDM Mathematics Education, 40 (1) 39-53.

Booker, G. (2009). Algebraic thinking: generalising number and geometry to express patterns and properties succinctly. Griffith University. Brisbane.

Cohen, L., Manion, L., \& Morrison, K. (2011). Research methods in education. Routledge: Madison Avenue, NY.

Dahar, R. W. (2006). Teori-teori belajar dan pembelajaran. Bandung: Erlangga.

Drijvers, P., Goddijn, A, \& Kindt, M. (2011). Algebra education: exploring topics and themes. Edited by Paul Drijvers. Secondary Algebra Education: Revisiting Topics and Themes and Exploring the Unknown. Rotterdam, Netherlands: Sense Publishers.

Feldman, R. S. (2011). Understanding psychology (10th ed.). New York, NY: McGraw-Hill.

Ferrucci, B. J. (2004). Gateways to algebra at the primary level. The Mathematics Educator, 8 (1) $131-38$.

Hidayanto, E. (2014). Transisi dari berpikir aritmetis ke berpikir aljabaris. Disertasi. Malang: PPS Universitas Negeri Malang.

Inganah, S. (2016). Karakteristik berpikir aljabar siswa pada level multi struktural dalam menggeneralisasi pola. Research Report, 305-14.

Kementerian Pendidikan dan Kebudayaan. (2016). Peraturan Menteri Pendidikan dan Kebudayaan Nomor 24 Tahun 2016 tentang Kompetensi Inti (KI) dan Kompetensi Dasar (KD) Pelajaran pada Kurikulum 2013 pada Pendidikan Dasar dan Menengah.

Kementerian Pendidikan dan Kebudayaan. (2013). Peraturan Menteri Pendidikan dan Kebudayaan Republik Indonesia Nomor 64 Tahun 2013 Tentang Standar Isi Pendidikan Dasar dan Menengah.

Departemen Pendidikan Nasional. (2006). Peraturan Menteri Pendidikan Nasional Republik Indonesia Nomor 23 Tahun 2006 Tentang Standar Kompetensi Lulusan Untuk Satuan Pendidikan Dasar dan Menengah.

Kieran, C. (2004). Algebraic thinking in the early grades/ : What is it? Mathematics Educator, 8 (1) $139-51$.

Lew, Hee-chan. (2004). Developing algebraic thinking in early frades: Case study of korean elementary school mathematics. The Mathematics Educator, 8 (1) 88-106.

Mason, J., Graham, A., \& Johnston-Wilder, S. (2005). Developing Thinking in Algebra. London: Paul Chapman Publishing. 
Morgil, I, \& Yörük, N. (2006). Cross-age study of the understanding of some concepts in chemistry subjects in science curriculum. Turkish Science Education, 3(1), 15-27.

NCTM. (2000). Principles and standards for school mathematics. School Science and Mathematics. The National Council of Teachers of Mathematics, Inc.: Reston, VA

Nursuprianah, I. \& Nisa, H. N, (2013). Pengaruh pemahaman konsep aritmatika terhadap kemampuan berpikir aljabar (studi kasus pada siswa kelas VII SMP Negeri 1 Ketanggungan Kabupaten Brebes). Eduma, 2(2).

Ormrod, J. E., \& Davis, K. M. (2012). Human learning (6th ed.). Upper Saddle River, New Jersey: Pearson Education, Inc.

Panasuk, R.M. (2010). Three phase ranking framework for assessing conceptual understanding in algebra using multiple representations. Education, 131 (2) 235-57.

Patton, B., \& Santos, E. D. L. (2012). Analyzing algebraic thinking using "guess my number" problems. International Journal of Instruction, 5 (1) 5-22.

Proulx, J. (2006). Making the transition to algebraic thinking: Taking students' arithmetic modes of reasoning into account. Delta-K, 44 (1) 8-16.

Puspita, I, Kaniawati, I, \& Suwarma, I. R. (2017). Student obstacles in solving algebraic thinking problems. Journal of Physics Conference Series, 895 (1) 1-6.

Radford, L. (2006). Algebraic thinking and the generalization of patterns: A semiotic perspective. PME-NA 2006 Proceedings, 1, 1-21.

Radford, L. (2010). Elementary forms of algebraic thinking in young students. Dalam Pinto M. F. \& Kawasaki T. F. (Eds.), Proceedings of the 34th Conference of the International Group for the Psychology of Mathematics Education, 4, 73-80.

Santrock, J.W. (2011). Educational psychology. 5thed. New York, NY: McGraw-Hill.

Taylor-Cox, J. (2003). Algebra in the early years? yes! Young Children, 58 (1) 14-21.

Ültay, N., \& Ültay, E. (2010). The development of chemistry concept in 7 th grade and 11 th grade/ : A cross-age study. Procedia -Sosial and Behavioral Sciences 2(2), 492-496.

Watson, A. (2007). Paper 6: Algebraic Reasoning. Dalam Key Understandings in Mathematics Learning. Nuffield Foundation.

Windsor, W. (2008). Algebraic thinking/ : A problem solving approach. Dalam L. Sparrow, B. Kissane \& C. Hurst (Eds.), Proceedings of the 33rd Annual Conference of the Mathematics Education Research Group of Australasia. Fremantle: MERGA. 